\title{
Bottlenecks in the coverage of the Israeli-Palestinian conflict: the coverage of the first and second intifadas in the Flemish press
}

\author{
Annelore Deprez and Karin Raeymaeckers \\ Ghent University, Belgium
}

\begin{abstract}
Various authors suggest that the public's knowledge of the Israeli-Palestinian conflict is inadequate. As it is generally accepted that public opinion on international news items is mainly formed by media content, the international media are often held responsible for sustaining the prevailing misconceptions about the Israeli-Palestinian conflict by covering the conflict parties in a biased and imbalanced way. This study focuses on the representation of Israelis and Palestinians in the news coverage of the first and second intifada by the Flemish press. By way of a content analysis, evolutions and discrepancies in the coverage of both intifadas are described in a longitudinal analytical perspective. The authors conclude that the portrayal of the Palestinian actors shifts from a rather positive view during the first intifada period to a more critical portrayal during the period of the second intifada. At the same time, there is an opposite move in the representation of the Israeli actors in the conflict. Although our results show differences in the distinct portrayals, they do not provide sufficient evidence to conclude unequivocally that the coverage of the first and second intifada is unbalanced. Indeed, the authors find that while some variables definitely favour the Israeli point of view (e.g. the use of sources), others clearly sustain the Palestinian side (e.g. the individualization of victims). In other words, the Flemish dailies cover the first and second intifada in quite a balanced way, contrary to what international studies on the coverage of the Israeli-Palestinian conflict have concluded regarding the media in different national settings.
\end{abstract}

\section{Keywords}

bias, first and second intifada, longitudinal content analysis, representation

\section{Corresponding author:}

Annelore Deprez, Department of Communication Sciences, Ghent University, Korte Meer 7-9-I I, 9000 Ghent, Belgium.

Email: Annelore.Deprez@UGent.be 


\section{Introduction}

Several studies (e.g. Philo and Berry, 2004; Rotik, 2006) show that the international public's inadequate understanding of the Israeli-Palestinian conflict is a consequence of their lack of factual knowledge. At worst, people have no information about the origins of the conflict at all; they are unable to identify the different actors and players in the conflict, and they have limited or no understanding of what is actually going on. Why is public opinion on this topic so limited, incomplete and often incorrect? Various authors find the answer in the news production processes of the international media. Although the news media cannot be held solely responsible for distorted public perceptions, they do play an important role in the shaping of the public's knowledge, especially as far as international issues are concerned.

In this light, our study investigates media content and media production processes in the reporting of the Israeli-Palestinian conflict in general, and of the first and second intifada in particular. We also examine the bottlenecks in news coverage. Following previous work by other researchers, we take the representation of victims, the communication of contextual information, the use of sources and the labelling of actions and actors to be elements in the impediment of adequate news production.

By examining Flemish daily newspapers, our study represents a new departure from previous research on the coverage of the Israeli-Palestinian conflict. Indeed, most empirical research into the coverage of the conflict has so far been concerned with Israeli and US media, whereas our study has an outspoken European/Flemish angle. It also focuses on the coverage of the conflict in traditional print media, whereas often-cited international studies centre on television coverage. Considering both the first and the second intifada permits a longitudinal perspective from which to draw conclusions regarding discrepancies or changes in coverage.

Specifically, we study the portrayal of Israelis and Palestinians in the news coverage of the first and second intifada by the Flemish dailies. A longitudinal content analysis allows us to draw conclusions regarding bias and shifts in representation between the first and the second intifada.

\section{Public opinion regarding the Israeli-Palestinian conflict: a consequence of media representation?}

The impact of the media on the construction and content of public opinion has been documented from different theoretical perspectives and in a growing number of empirical studies. Starting with the agenda-setting theory in the early 1960s, the content and building of media messages as a determining factor for the construction of public opinion has been extensively discussed (Cohen, 1963; McCombs, 2004; McCombs and Shaw, 1972, 1977, 1993). Other theories, such as priming and framing, adjusted and refined this theory, focusing on specific aspects of agenda setting. For instance, the priming effect (e.g. Iyengar and Kinder, 1987; Krosnick and Brannon, 1993; Krosnick and Kinder, 1990; Pan and Kosicki, 1997; McCombs and Reynolds, 2002) is 'especially one of promoting certain evaluative criteria and it plays a part in attempts to manage news' (McQuail, 2005: 514). Framing theory, on the other hand, specifically focuses on journalistic frames in media content and how these media frames influence their audiences in what they learn and how 
they think about certain issues (Dente Ross, 2003; Entman, 1991; Gamson, 1992; Gamson and Lasch; 1983; McQuail, 2005; Semetko and Valkenburg, 2000).

These theoretical perspectives support the idea that the way in which the media represent the Israeli-Palestinian conflict and the parties involved has a direct impact on what and how the public think about it. The media can represent one party as the perpetrator and the other as the victim by using specific labels, painting vague contextual background, and using only one conflict perpetrator as a source for their coverage.

Various authors (e.g. Philo and Berry, 2004; Rotik, 2006) focus on the public's perception and knowledge of the Israeli-Palestinian conflict. In an international comparative research setting based on surveys, Philo and Berry (2004) tested the levels of knowledge about the background of the Israeli-Palestinian conflict. Very few of the British, German and US respondents were able to answer questions such as 'Who is the occupier?', 'What are the origins of the refugee problem?' and 'Are colonists Israeli or Palestinian people?' Rotik (2006) confirmed this lack of knowledge about the Israeli-Palestinian conflict. Her survey research showed that as many as 71 per cent of the respondents had little if any knowledge, while only 3 per cent had a performant knowledge; 59 per cent of the respondents stated that a dispute about territorial division was the cause of the conflict, while 38 per cent thought that the conflict between the Israeli and the Palestinian people was of a religious nature. Also the question of oil supply and the intervention of the US were often identified as causes of the conflict.

These findings are significant because adequate knowledge of the background of a conflict is necessary to understand its causes and developments and to form a well-based opinion. The studies just cited clearly show that, at present, the public's understanding of the Israeli-Palestinian conflict is too strictly based on sentiment and lack of knowledge.

Although the studies by Philo et al. (2004) and Rotik (2006) indicate the current levels of knowledge and perception of the conflict among the public, they do not investigate the role the media may play in the construction of a distorted representation. To throw some light on the latter, how the media ultimately portray the Israeli-Palestinian conflict should be examined. Do they publish contextual background? How do they label actors and actions? Which sources do they use to cover the conflict?

\section{The representation of the Israeli-Palestinian conflict in international media coverage}

Several authors have undertaken research into the representation of the Israeli-Palestinian conflict. Table 1 groups these studies and indicates their respective emphasis or focus.

Table 1 shows that the studies mainly concern the presence of contextual information, the choice of labels, the reporting on victims and the use of Israeli and Palestinian actors as sources. Nearly all studies conclude that the media represent Israelis and Palestinians differently. The studies generally observe a bias in favour of the Israelis. However, it must be said that these studies have especially focused on the Israeli and US media. Studying other national and political contexts may perhaps reveal other conclusions.

As for the presentation of contextual data, several studies highlight a lack of background information in the coverage of the Israeli-Palestinian conflict. As a result, the motives of Israelis as well as of Palestinians remain unclear (e.g. Dunsky, 2001; Loughborough 


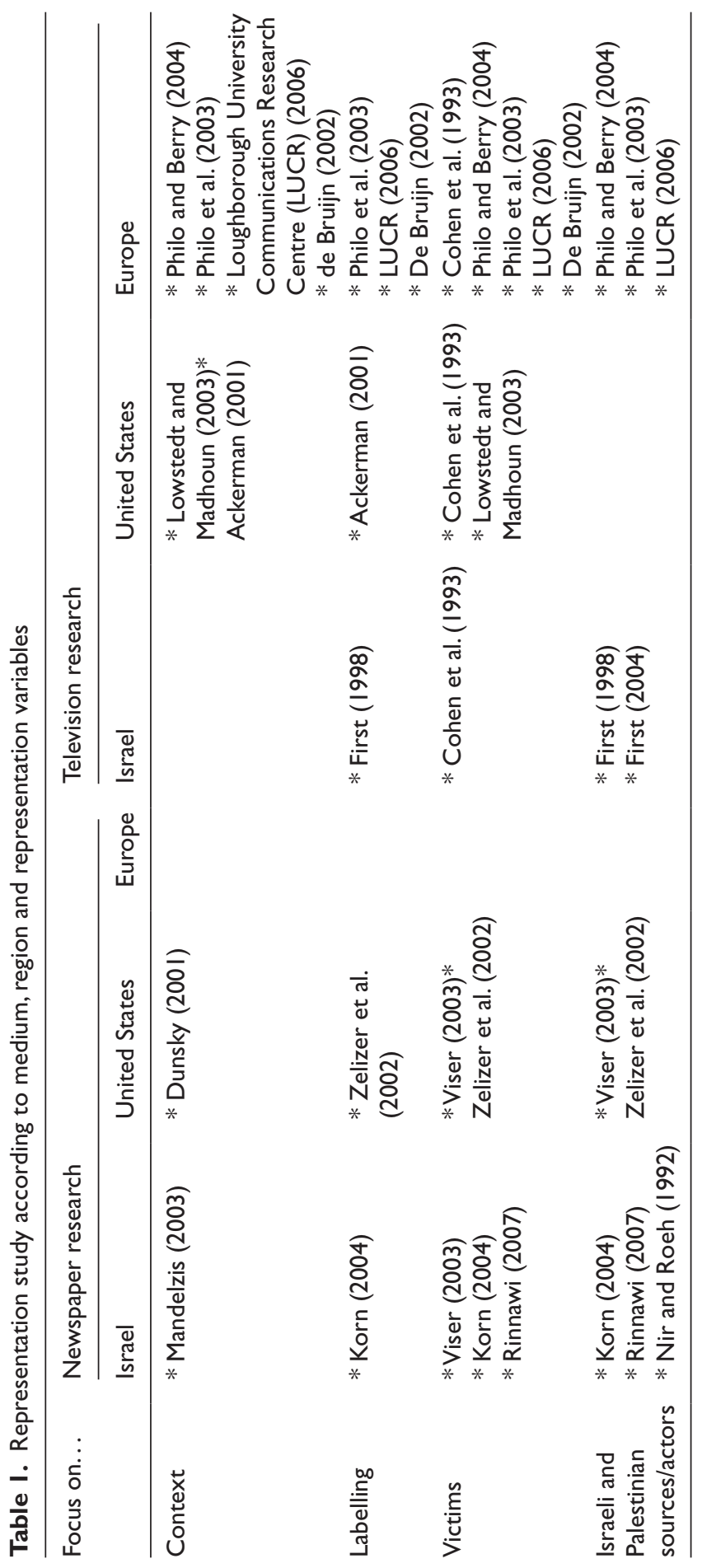


University Communications Research Centre, 2006; Mandelzis, 2003; Philo and Berry, 2004). Almost all the media, whether closely associated with the conflict or not, provide only minimal background on the history of the conflict. Indeed, as Dente Ross (2003: 62) puts it: 'History means last week or last year' (emphasis added). In addition, when contextual data are included in the media coverage, it is mainly the Israeli point of view that is reflected. As a rule, Israelis are portrayed as the victims and Palestinians as the aggressors.

Studies on the labelling of actors and actions also reveal some discrepancies in the coverage. The Palestinian conflict perpetrator, especially, is found to be disadvantaged (Ackerman, 2001; De Bruijn, 2002; First, 1998, 2004; Korn, 2004; Loughborough University Communications Research Centre, 2006; Philo et al., 2003; Zelizer et al., 2002). Research by Weimann (1985), Picard and Adams (1991) and Simmons (1991) shows that labels can be classified according to their positive, negative or neutral content. For example, labels such as murderer, gunmen, saboteurs, terrorists, criminals, kidnappers, assassins and hijackers have a negative connotation. Neutral words are guerrilla, army, underground, separatists, organization, movement commandos, group and front. Positive terms are freedom fighter, liberation organization, independence movement and patriots (Weimann, 1985: 436; Weimann and Winn, 1993: 193). While the Israelis and their actions are principally described in positive terms, Palestinians are very often labelled negatively. For instance, Palestinian actions are mostly related with terrorism, while Israeli lethal actions are described as necessary measures to protect the country against hostile attacks by the Palestinians. Those discrepancies also apply to the labelling of the Palestinian territories. 'Disputed' territories - a positive label that is preferred by the Israelis - is more often used than 'occupied' territories (De Bruijn, 2002; Fisk, 2005; Zelizer et al., 2002). The same applies to the portrayal of victims. Palestinians are 'killed' or 'lose their lives' (rather neutral words), Israelis are 'murdered' or 'lynched' (De Bruijn, 2002; Fisk, 2005: 604; Korn, 2004: 255; Philo et al., 2003).

Moreover, Palestinian victims are reported without personal features. In headlines, Palestinians are portrayed as perpetrators and Israelis as victims. Figures of the numbers of victims are proportionally incorrect. Even when more Palestinians than Israelis are killed in an incident, the coverage tends to assume that there are more Israeli victims (e.g. Cohen et al., 1993; Korn, 2004; Rinnawi, 2007; Viser, 2003; Zelizer et al., 2002).

Finally, authors who examine the relative numbers of Palestinian and Israeli actors as sources for news stories conclude that Palestinian sources are underrepresented in international news coverage. It goes without saying that Israeli media chiefly rely on Israeli sources. The US media, however, consult US and Israeli sources, but very few Palestinian sources. The British media pay some attention to Palestinian sources, but still use Israeli sources more often (First, 1998; Korn, 2004; Loughborough University Communications Research Centre, 2006; Philo and Berry, 2004; Philo et al., 2003; Rinnawi, 2007; Viser, 2003; Zelizer et al., 2002).

These studies show that the international media coverage of the Israeli-Palestinian conflict is biased and imbalanced. It follows that the media appear to be at least partly responsible for the public's inadequate perception of the conflict. The way in which the media produce news and cover events concerning the Israeli-Palestinian conflict shapes and promotes a certain image. However, the question remains to what degree the conclusions of these empirical studies can be generalized to all media. In other words, will an examination of the coverage of the Israeli-Palestinian conflict in the Flemish press yield the same conclusions? 
Table 2. Articles according to newspapers and intifada

\begin{tabular}{llll}
\hline & The first intifada (\%) & The second intifada (\%) & Total (\%) \\
\hline DS & $120(43.2)$ & $158(56.8)$ & $N=278(30.0)$ \\
DM & $91(38.7)$ & $144(6 I .3)$ & $N=235(25.4)$ \\
HLN & $69(58.5)$ & $49(4 I .5)$ & $N=118(12.7)$ \\
HV & $56(53.3)$ & $49(46.7)$ & $N=105(11.3)$ \\
FET & $53(27.9 \%)$ & $137(72.1)$ & $N=190(20.5)$ \\
Total & $N=389(42.0)$ & $N=537(58.0)$ & $N=926$ \\
\hline
\end{tabular}

$p<.001 ; \chi^{2}=35.390$

In the following section, we describe the representation of the first and second intifada in the Flemish press. We consider various variables (see later) that will allow us to establish the degree of bias and imbalance in the coverage. We further aim to uncover possible changes in the Flemish newspaper coverage between the first and the second intifada.

\section{The coverage of the first and second intifada in the Flemish press: imbalance and bias?}

\section{I Methodology}

In a longitudinal content analysis including the central variables of context, victims, sources and labelling, we study a sample of 926 newspaper articles on the intifada. Only articles that directly relate to the first or the second intifada are included, while articles on elections, peace negotiations and other topics that do not immediately concern the intifada are excluded.

In the literature, the period from 1987 to 1993 is marked as the first intifada (Ismail, 2010; Noakes and Wilkins, 2002). The second intifada begins in 2000 and ends in 2005 (Liebes and Kampf, 2009). For the first intifada, we specifically selected the following periods: 1 October 1987 to 31 March 1988, 1 October 1989 to 31 March 1990, and 1 October 1991 to 31 March 1992. For the second intifada, we selected the following periods: 1 October 2000 to March 31 2001, 1 October 2002 to 31 March 2003, and 1 October 2004 to 31 March 2005. We included five Flemish newspapers that were published in the selected periods (see later). A preliminary research on one artificial week - composed according to a stratified sample with constructed weeks -showed that this sample was too small to identify significant findings. ${ }^{1}$

Table 2 indicates that eventually 537 articles on the first intifada and 389 articles on the second intifada were included. The analysis was carried out in five national daily newspapers that are representative of the Flemish newspaper market: De Standaard (DS), De Morgen (DM), De Financieel Economische Tijd/De Tijd (FET), Het Volk (HV) and Het Laatste Nieuws (HLN). De Standaard, De Morgen and De Financieel Economische Tijd/De Tijd are quality newspapers, while Het Volk and Het Laatste Nieuws are popular newspapers. Table 2 indicates that 278 articles were found in De Standaard, 235 in De Morgen, 190 in De Financieel Economische Tijd/De Tijd, 105 in Het Volk and 118 in Het Laatste Nieuws.

We verified the validity and reliability of the researched variables: context, victims, sources and labelling. Since our sample is a representative construction, the studied variables 
Table 3. The amount of textual information

\begin{tabular}{|c|c|c|}
\hline & Is present (\%) & $\begin{array}{l}\text { Is extensively } \\
\text { discussed (\%) }\end{array}$ \\
\hline The illegality of Jewish settlements & $3.8(N=35)$ & $0.2(N=2)$ \\
\hline The existence of Israeli checkpoints & $3.9(N=36)$ & $0.1(N=1)$ \\
\hline A network of roads for Israelis only & $1.3(N=12)$ & $0.0(N=0)$ \\
\hline The occupation of Palestinian territories & $39.0(N=61)$ & $2.9(N=27)$ \\
\hline The expropriation of Palestinian territories & $1.7(N=16)$ & $0.0(N=0)$ \\
\hline American involvement and aid for Israelis & $14.4(N=133)$ & $1.6(N=15)$ \\
\hline $\begin{array}{l}\text { Zionism as justification for occupying } \\
\text { Palestinian territories }\end{array}$ & $1.6(N=15)$ & $0.0(N=0)$ \\
\hline $\begin{array}{l}\text { The holocaust as justification for occupying } \\
\text { Palestinian territories }\end{array}$ & $0.3(N=3)$ & $0.0(N=0)$ \\
\hline $\begin{array}{l}\text { Islam as justification for fighting against Israeli } \\
\text { occupation }\end{array}$ & $0.8(N=7)$ & $0.1(N=1)$ \\
\hline Unequal distribution of water & $0.0(N=0)$ & $0.0(N=0)$ \\
\hline The problem of Palestinian refugees & $15.4(N=143)$ & $0.8(N=7)$ \\
\hline The special status of Jerusalem & $4.9(N=45)$ & $0.4(N=4)$ \\
\hline Israelis acting to guarantee their own security & $10.8(N=100)$ & $4.5(N=42)$ \\
\hline Israelis acting against Palestinian terror & $14.0(N=130)$ & $4.5(N=42)$ \\
\hline The occupation of 1967 & $0.1(N=I)$ & $0.0(N=0)$ \\
\hline The Green Line & $0.1(N=I)$ & $0.0(N=0)$ \\
\hline Historical background of the intifada & $0.1(N=I)$ & $0.1(N=1)$ \\
\hline Sharm-el-Sjeikh summit & $0.2(N=2)$ & $0.2(N=2)$ \\
\hline $\begin{array}{l}\text { Religion as justification for occupying } \\
\text { Palestinian territories }\end{array}$ & $0.1(N=1)$ & $0.0(N=0)$ \\
\hline The construction of a 'security wall' & $0.1(N=1)$ & $0.1(N=1)$ \\
\hline
\end{tabular}

are operationalized and defined, and the statistical analysis is based on techniques applied to the used nominal research variables, we can confirm that the validity of our study is high. In addition, the inter-coder reliability test, performed by a pair of coders, showed Cohen's Kappas ranging from 0.75 to 1.00 for the context, victims, sourcing and labelling variables. In other words, these Kappa-coefficients indicate a high reliability too.

\subsection{Results}

The amount of contextual information. Various international studies (see earlier) conclude that contextual information is lacking in the coverage of the Israeli-Palestinian conflict. Consequently, the public has difficulty understanding the background, the salient points and the development of the conflict.

Our analysis exposes the minimal reporting of context. Table 3 shows that only the connection between Israel and the occupation of Palestinian territories is frequently mentioned. Also, information related to the US involvement in the conflict is often conveyed; the problem of Palestinian refugees is considered, and Israeli actions are framed in the 
Table 4. The presence and place of motivation for actions in newspaper articles.

\begin{tabular}{lllllll}
\hline & $\begin{array}{l}\text { Motives } \\
\text { present } \\
(\%)\end{array}$ & $\begin{array}{l}\text { Motives } \\
\text { not } \\
\text { present } \\
(\%)\end{array}$ & $\begin{array}{l}\text { Motives } \\
\text { before } \\
\text { incident } \\
(\%)\end{array}$ & $\begin{array}{l}\text { Motives } \\
\text { after } \\
\text { incident } \\
(\%)\end{array}$ & $\begin{array}{l}\text { Not } \\
\text { applicable } \\
(\%)\end{array}$ & $N$ \\
\hline Palestinian act & 24.8 & 75.2 & 2.7 & 22.1 & 75.2 & $N=335$ \\
Israeli act & 51.8 & 48.2 & 4.6 & 47.2 & 48.2 & $N=668$ \\
Confrontation & 35.4 & 64.6 & 12.5 & 48.2 & 64.6 & $N=195$ \\
& 41.6 & 58.4 & 4.2 & 37.4 & 58.4 & \\
& $N=498$ & $N=700$ & $N=50$ & $N=448$ & $N=700$ & $N=1198$ \\
& $P<.001$ & $\chi^{2}=70.731$ & & $p<.001$ & $\chi^{2}=72.613$ & \\
\hline
\end{tabular}

context of defence against terror and the need for security. Other important contextual elements concerning the main points (Jerusalem, water supply, settlements) or the origins of the conflict (Zionism, the holocaust) are rarely explored. Furthermore, it is striking that contextual data are rarely expanded. Journalists may just mention the difficult status of Jerusalem, but omit to frame it.

Striking differences can be observed between the first and second intifada as far as the amount of contextual information is concerned. In the coverage of the first intifada, Israel is explicitly labelled as an occupying power. It is implied that, by occupying Palestinian territories, the Israelis provoke Palestinian actions. The articles regarding the second intifada still mention the occupation, but no longer connect it with Israel. We observe an increasing number of references to the Israelis acting against terror. In other words, Palestinians are no longer reacting against the occupation, but Israelis are now acting against Palestinian terrorists in order to safeguard their own security.

Various authors focus on the presence of a general contextualization, but some also investigate the contextual information regarding specific Palestinian or Israeli actions (e.g. De Bruijn, 2002). Most of those studies conclude that Palestinian actions are rarely explained and, when a Palestinian act is explained, its motives are published after the news fact. On the contrary, Israeli actions are mostly interpreted and motives are explained before describing the act against Palestinians.

In our sample of 926 newspaper articles, we identify and examine 335 Palestinian actions, ${ }^{2} 668$ Israeli actions, and 195 confrontations between Palestinians and Israelis. Table 4 shows that, when motives are mentioned (which is the case in $41.6 \%$ of the articles), they tend to support Israeli actions. Indeed, in 51.8 per cent of the studied articles, we can identify motives for Israeli actions, while only 24.8 per cent report any motivation for Palestinian actions. However, it would be incorrect to state that motives for Israeli actions are published before the news fact. Motives both for Israeli and for Palestinian actions mostly appear after the description of the incident itself.

The labelling of Israelis and Palestinians. Regarding the labels that describe Palestinians and Israelis, our study shows a very limited variety in terms. Nonetheless, an extensive list of words, chosen on the basis of earlier research on the Israeli-Palestinian conflict was researched (e.g. Ackerman, 2001; De Bruijn, 2002; First, 1998, 2004; Korn, 2004; 
Table 5. Labels for Palestinians and Israelis

\begin{tabular}{lcc}
\hline & Palestinian & Israëli \\
\hline Activist & 52 & 4 \\
Movement & 124 & 12 \\
Occupier & 0 & 32 \\
Extremist & 67 & 18 \\
Fundamentalist & 28 & 2 \\
Group & 85 & 5 \\
Guerrilla fighter & 42 & 1 \\
Martyr & 19 & 5 \\
Militant & 74 & 7 \\
Murderer & 8 & 2 \\
Organization & 101 & 10 \\
Radical & 94 & 4 \\
Fighter & 35 & 1 \\
Terrorist & 108 & 24 \\
Suicide & 18 & 1 \\
\hline
\end{tabular}

Loughborough University Communications Research Centre, 2006; Philo et al., 2003; Picard and Adams, 1991; Simmons, 1991; Weimann, 1985; Zelizer et al., 2002). Words such as 'underground movement', 'patriot', 'saboteur' and 'assassin' are not represented. Labels such as 'anti-Semite', 'home guard', 'criminal', 'fanatic', 'front', 'nationalist', 'independence movement', 'racist', 'separatist', 'freedom fighter', 'enemy', 'liberation movement', 'resistance fighter' and 'suicide activist' are hardly used. The question remains what basic labels are used to describe Palestinians and Israelis.

Table 5 shows that 'activist', 'extremist', 'fundamentalist', 'guerrilla fighter', 'martyr', 'militant', 'murderer', 'organization', 'movement', 'radical', 'fighter', 'terrorist', and 'suicide' are labels that are often used to describe Palestinians. Only the word 'occupier' is more often used to label the Israeli actor. In other words, labels charged with meaning are more closely related to the Palestinian conflict perpetrator.

Our study confirms that Palestinians are predominantly portrayed as terrorists rather than martyrs (e.g. Zelizer et al., 2002). The 'freedom fighter' and 'resistance fighter' labels are usually neglected in the coverage. On the other hand, we notice that the 'occupying army' label, referring to the Israeli actor, occurs several times, but the use of this label is rather rare in comparison with labels such as 'terrorist', 'radical' and 'extremist' that are used to describe Palestinians (e.g. De Bruijn, 2002).

The labelling of Palestinian and Israeli actions. Not only are Israeli and Palestinian actors described with certain labels, but their actions are also associated with typical words. Our content analysis shows that labels such as 'interception', 'misunderstanding', 'miscalculation', 'slaughter' and 'intervention' are not mentioned in articles on the first and second intifada. Moreover, the 'barbarian', 'aimed attack', 'murder', 'tragedy', 'safety act' and 'mistake' labels are hardly ever used. On the other hand, the labels in Table 6 are constantly applied throughout. 
Table 6. Labels for Palestinian and Israeli actions

\begin{tabular}{lcc}
\hline & Palestinian act & Israeli act \\
\hline Attack & 700 & 66 \\
Act & 73 & 149 \\
Massacre & 17 & 13 \\
Incident & 83 & 103 \\
Invasion & 0 & 34 \\
Military operation & 1 & 17 \\
Offensive & 0 & 52 \\
Operation & 7 & 95 \\
Raid & 32 & 63 \\
Skirmish & 19 & 22 \\
Act of terror & 32 & 4 \\
Revenge & 10 & 20 \\
\hline
\end{tabular}

The 'attack' label is mentioned remarkably often in the sampled articles. And it is mainly used to illustrate Palestinian actions. Also the labels 'massacre' and 'act of terror' are predominantly attached to Palestinian actions. However, it is striking that those words are used only occasionally. Consequently, we have to modify the conclusion that the 'massacre' label mainly occurs in relation to Palestinian actions (e.g. Fisk, 2005). The label is not so often used as some studies suggest (see earlier), and Israelis are acknowledged to cause massacres as well.

Table 6 also indicates that the more negative labels such as 'invasion', 'raid' and 'revenge' are more often related to Israeli actions. However, it is important to mention that no preponderance, such as that noticed in earlier studies regarding the word 'attack', can be observed. This means that the labels mentioned are more used in combination with Israeli actions, but still also appear in relation to Palestinian actions. Besides, the more neutral words 'action', 'incident', 'military offensive', 'operation', 'offensive' and 'skirmish' are likely to be predominantly associated with Israeli actions.

'Disputed'vs 'occupied'territories and 'colonies'vs 'settlements' and 'neighbourhoods'. Other words that are often discussed are those that relate to the Palestinian territories and the Jewish enclaves (e.g. De Bruijn, 2002; Fisk, 2005; Zelizer et al., 2002). In the coverage of the first and the second intifada, the 'disputed' label is rarely used in the articles in our sample; the term 'occupied' dominates completely. We must not conclude, therefore, that the Israeli terminology is merely copied by the Flemish dailies. This is not the case with such terms as 'colonies', 'settlements', 'illegal settlements' and 'neighbourhoods'. Flemish journalists tend to talk about 'colonies' and 'settlements', rather than about 'neighbourhoods' and 'illegal settlements'. Besides, our analysis shows that the term 'settlement' is most represented by far. The more negatively loaded 'colonies' label appears less frequently.

Victims and perpetrators in articles on the first and second intifada. We also examined whether personal information on victims is conveyed in the newspaper articles and the type of personal information revealed. Table 7 shows that the representation of personal data is 
Table 7. Representation of personal information on victims

\begin{tabular}{llllr}
\hline $\begin{array}{lll}\text { Palestinian } \\
\text { victims }\end{array}$ & Personal & $\mathbf{4 1 . 6}$ & Name & 12.9 \\
$(\mathrm{~N}=690)$ & information & & Age & 34.8 \\
& & & Marital status & 0.3 \\
& & Profession & 8.0 \\
Israeli & & Other & 2.2 \\
victims & Personal & 24.9 & Name & 5.3 \\
$(N=394)$ & information & & Age & 12.7 \\
& & & Marital status & 1.0 \\
& & & Profession & 9.4 \\
& & & Other & 0.8 \\
\hline
\end{tabular}

completely different from the picture that emerged from numerous previous studies (see earlier). Indeed, the Palestinians rather than the Israeli victims are predominantly described on the basis of personal data. The figures concerning the Palestinian actors show that 690 articles refer to victims. No fewer than 41.6 per cent of these articles not only identify these victims, but also specify personal information. This information mostly contains the name $(12.9 \%)$, age $(34.8 \%)$, marital status $(0.3 \%)$, or profession $(8.0 \%)$. Combinations of personal elements also occur.

The figures regarding the Israeli actor clearly show that a lower number of articles refer to Israeli victims. The fact that only 394 articles mention Israeli victims does not mean that those victims are less extensively covered. Newspapers can opt to zoom in on those victims by communicating a large amount of personal data. However, our figures show that 24.9 per cent of the relevant 394 articles focus on individual elements. This percentage is considerably lower than the one that expresses the representation of individual data regarding Palestinian victims. We can conclude that the Flemish press has paid less attention to individual data concerning Israeli victims. Their names are mentioned in 5.3 per cent of the relevant articles, their age in 12.7 per cent, marital status in 1.0 per cent and profession in 9.4 per cent of the sampled articles.

Previous studies (see earlier) have shown that, especially in headlines, Palestinians are more likely to be portrayed as perpetrators and Israelis as victims. Headlines also link Israeli victims to positive labels and Palestinians to negative ones. These findings make it interesting to focus specifically on the perpetrator-victim roles and the labelling of victims in the headlines of our sample of newspaper articles.

If we focus on the newspaper headlines, we may conclude that Palestinians, more than Israelis, are victimized in headlines $(18.1 \%$ vs $6.9 \%)$, while Israelis are more often portrayed as perpetrators $(12.1 \%$ vs $9.3 \%)$. These findings are contrary to other international studies (e.g. Korn, 2004; Rinnawi, 2007; Viser, 2003). A breakdown of the figures per intifada reveals no significant differences in the attribution of the victim role. It is clear that the coverage of both intifadas mentions more Palestinian victims in its headlines. As far as the perpetrator role is concerned (Table 8) we find some discrepancies. Only 3.9 per cent of articles on the first intifada portray Palestinians as perpetrators in their headlines. This percentage rises to 13.2 per cent during the second intifada. This result clearly supports the view of Palestinians as victims during the first intifada. However, the Israelis 
Table 8. Palestinian and Israeli perpetrators in headlines divided by intifada

\begin{tabular}{llll}
\hline & $\begin{array}{l}\text { Palestinian } \\
\text { perpetrators (\%) }\end{array}$ & $\begin{array}{l}\text { Israeli } \\
\text { perpetrators (\%) }\end{array}$ & Total (\%) \\
\hline First intifada & 3.9 & 8.7 & 12.6 \\
Second intifada & 13.2 & 14.5 & 27.7 \\
& $9.3(N=86)$ & $12.1(\mathrm{~N}=1 \mid \mathrm{I})$ & $21.4(\mathrm{~N}=198)$ \\
& $p<.001$ & $p<.05$ & \\
& $\chi^{2}=24.436$ & $\chi^{2}=10.692$ & \\
\hline
\end{tabular}

undergo a similar evolution. The portrayal in headlines of Israeli perpetrators increases also between the first and the second intifada. In other words, Israelis are not portrayed more often as perpetrators during the first intifada than during the second intifada.

The findings of the labelling of victims in headlines are quite surprising. Only 98 headlines are relevant for this part of the study. The same labels are used to describe Palestinian and Israeli victims. Few headlines contain 'murder', 'losing life' or 'being killed'. The 'killed' label is often used; 41 and 7 titles, respectively, mention the term in relation to Palestinian and Israeli victims. 'Shot to death' and 'killed off' are also used; 30 headlines use those words to refer to Palestinian victims, as opposed to 7 headlines for Israeli victims. More neutral terms such as 'dying' and 'losing their lives' are not found in the headlines. Phrases such as 'claiming lives' and 'costing lives' are mentioned in 6 headlines (equally divided between Palestinian and Israeli victims). 'Murdered' and 'being slaughtered', which occur 5 and 2 times, respectively, are also less frequently used labels.

These data indicate that Palestinian as well as Israeli victims are predominantly 'killed'. There is no significant difference in their labelling. Broadening the study to include all the sample articles yields similar results. The 'killed' label is often used for Israeli as well as for Palestinian victims. However, the most frequently found label is 'losing their lives'. This label is often used in the body of the article, rather than in the headline. Negatively loaded words such as 'slaughtered' and 'murdered' are rarely present in either the headline or the body of the article. As far as the 'slaughter' label is concerned, we can conclude that if it is used at all, it is in relation to Israeli victims. Palestinians are never 'slaughtered'.

The use of sources. Various authors (e.g. First, 1998; Korn, 2004; Loughborough University Communications Research Centre, 2006; Philo and Berry, 2004; Philo et al., 2003; Rinnawi, 2007; Viser, 2003; Zelizer et al., 2002) indicate that there is an uneven representation of Israeli and Palestinian sources in the media. Our study indicates that 30.1 per cent of the articles reflect only Israeli sources (sometimes in combination with other, though not Palestinian, sources) (Table 9). The comparative figure regarding the use of Palestinian sources is 8.7 per cent. Although the figures show that Israelis are more present as a source than Palestinians, 45.5 per cent of the articles mention both sources. Consequently, we can confirm that Israeli sources are more often cited, but that there is also space for Palestinian sources in Flemish newspapers.

Looking at the coverage of the first and the second intifada separately, we can see that 78.7 per cent of the researched articles on the first intifada cite an Israeli source. During 
Table 9. Sources used in the coverage of the first and second intifada

\begin{tabular}{lc}
\hline & Present (\%) \\
\hline Israeli sources & 22.2 \\
Israeli and other sources & 7.9 \\
Israeli and Palestinian sources & 28.4 \\
Israeli, Palestinian and other sources & 17.1 \\
Palestinian sources & 6.8 \\
Palestinian and other sources & 1.9 \\
Other sources & 3.1 \\
No sources & 12.5 \\
\hline
\end{tabular}

Table 10. The use of sources split up into categories

\begin{tabular}{llc}
\hline Israeli source (\%) & Category & Palestinian source (\%) \\
\hline 31.2 & Military & - \\
- & Terror & 12.4 \\
46.4 & Political & 29.5 \\
14.3 & Media & 4.1 \\
8.5 & Citizen & 14.4 \\
7.0 & Security & 2.4 \\
15.4 & Other & 13.2 \\
\hline
\end{tabular}

the second intifada, this figure decreases slightly to 73.2 per cent. No more than 47.8 per cent of the articles refer to Palestinian actors during the first intifada, while 58.8 per cent of the articles on the second intifada mention a Palestinian source. The figures indicate that, during the first as well as the second intifada, more Israeli sources are cited. However, it is striking that the amount of Palestinian sources significantly increases in the coverage of the second intifada.

A further question that comes up is identification of the cited sources. To formulate an answer, we divided the various sources into categories. Table 10 shows that Israeli military and political sources are referred to especially. Palestinian sources that are often used are politicians and citizens. Terrorists are also cited. ${ }^{3}$

The examination of the status of sources indicates that military sources are often anonymously cited. When the status of those spokespersons can be determined, we find a prevalence of individuals in a high military position, with high status. Frequently mentioned Israeli military sources in the coverage of the first intifada are Chief of Staff Shomrom, General Mitzna and former Chief of Staff Mordechai. In the coverage of the second intifada, Chief of Staff Mofaz (2000-2001) and General Ziv are quoted several times.

Terrorist sources are less individualized as journalists mostly mention the name of the terrorist group rather than its individual members. When members of terrorist groups are quoted, it is striking that they hold an important position within the group. The (co)founders of Hamas - al-Rantissi and Sheikh Yassin, in particular - are quoted more than once in newspaper articles on the second intifada. 
Political sources are the least frequently quoted anonymously and there is a predominance of sources with a high status (see Tables 11 and12). Often used Israeli sources in the coverage of the first intifada are Prime Minister Shamir, Minister of Defence Rabin and Minister of Foreign Affairs Peres. These three sources together account for as many as 146 citations in the researched articles. Often quoted Palestinian sources are PLO-leader Arafat and the Palestinian leader Faisal al-Hoesseini but they account for only 33 citations. We notice, in other words, a certain kind of imbalance in citations; during this first intifada, in particular, the number of Palestinian political sources is low.

In the coverage of the second intifada Prime Ministers Barak (1999-2001) and Sharon (2001-2006), Ministers of Defence Ben-Eliezer (2001-2002) and Mofaz (2002-2005) and Ministers of Foreign Affairs Ben-Ami (2000-2001), Peres (2001-2002) and Netanyahu (2002-2003) are summarized and cited several times. They dominate the coverage with as many as 224 references. On the Palestinian side, we notice a more diverse use of sources. Arafat is still the most frequently cited Palestinian leader, but also Erekat, Abbas, Rabbo and Barghouti are used as sources (see Table 12). Erekat is especially consulted in his capacity of main negotiator with the Israelis, but also as Minister of Cabinet Affairs. Abbas is the Prime Minister of the Palestinian Authority, and in Europe and the US he is looked upon as a suitable participant in peace negotiations. During the second intifada, Rabbo is Minister of Information, while Barghouti is a major Fatah leader who was a candidate for the presidential elections of the Palestinian Authority in 2004.

Finally, media and security sources are very often anonymously represented. Only for the citizen sources can we find numerous citations from persons with lower status. Their presence is often based on being an eyewitness. We find a proportional representation of those portrayed anonymously and those mentioned by name.

These results make it clear that, unlike other studies, we cannot conclude that Israeli sources have a higher status and are more often mentioned by name than Palestinian sources.

\section{Conclusion}

Various studies have concluded that the public's knowledge and interpretation of the Israeli-Palestinian conflict are inadequate. The media are often held partially responsible for this lack of knowledge and bias in public opinion. International studies highlight media coverage that favours the Israelis but this coverage is also found to be incomplete.

Our study examines to what extent earlier results and findings that indicate imbalance and bias in the international coverage of the Israeli-Palestinian conflict would compare with the coverage in the Flemish dailies. We also wanted to study possible discrepancies in coverage between the first and the second intifada.

We can conclude that the results of our study of the coverage of the first and second intifada in the Flemish dailies do not always support those of other international representation studies. Only the findings on the representation of contextual information are quite similar. The overall absence of contextual elements is confirmed, i.e. too little background and context are reported in the articles on the first and second intifada. Our study made it necessary to modify the generally accepted view that Israeli-supported terminology is used in the labelling of actors, actions and victims. For example, the 'occupied' label is far more often reported than the 'disputed' label. However, we notice that negatively loaded labels are more often associated with Palestinian actors. 
Table I I. Israeli political sources

\section{Position}

Mentioned

\section{First intifada}

Shamir

* Prime minister (1987-1988 and 1991-1992)

Rabin

* Minister of Defence

Peres

* Minister of Foreign Affairs (1992)

26

Arens

* Minister of Defence

\section{Second intifada}

Sharon

* Minister of Foreign Affairs

Barak

* Prime minister (since 6/2/200I) 87

* Prime minister (until 6/2/200I) 68

* Minister of Foreign Affairs (2004-2005)

Mofaz

* Chief of staff army (2000-200I)

* Minister of Defence(2002-2005)

Ben-Eliezer

* Minister of Defence(200I-2002)

Peres

* Minister of Foreign Affairs (200I-2002)

Netanyahu

* Minister of Foreign Affairs (2002--2003)

Ben-Ami

* Minister of Foreign Affairs (2000-200I)

Table 12. Palestinian political sources

Position

\section{First intifada}

Arafat

al-Hoesseini

Rabbo

* Palestinian leader and president

* Palestinian leader 8

\section{Second intifada}

Arafat

* Member of the Executive Committee PLO

* Palestinian leader and president

Erekat

* Minister of Cabinet Affairs

* Top negotiator

Abbas

* Prime Minister PA (in 2003)

* President PA (since 2005)

Rabbo

* Minister of Information

Barghouti

* Fatah-leader

* Candidate presidential elections in 2004

The same does not apply to the description and individualization of victims. Palestinians are more individualized than Israelis: their names, profession, marital status, etc. are more often mentioned than those of Israeli victims. These conclusions run counter to findings in various previous international studies.

The examination of the use of sources, however, reveals that, during both intifadas, Israeli sources are more often referred to than Palestinian ones. 
Our data show some discrepancies in the coverage of the first and second intifada. The image of Palestinians shifts from rather positive to rather negative between both intifadas, while there is a reverse pattern for the Israeli image. Israel is given the role of occupying force during the first intifada and Palestinians are the victims. In the period of the second intifada, Israelis are the victims, while Palestinians are perpetrators of actions of terror.

A straight answer to the central question of whether the coverage of the first and second intifada is unbalanced cannot be given, in spite of the fact that discrepancies and shifts are definitely present. The observed discrepancies, however, do not always in favour of the same conflict perpetrator. Some researched variables obviously play into Israeli hands (e.g. the use of sources), others are in favour of the Palestinian actor (e.g. the individualization of victims). In other words, in contrast with international news media, the overall coverage of the conflict in the Flemish daily newspapers is reasonably balanced.

\section{Notes}

1. Neither would the selection of two or more artificial weeks have resulted in the required number of articles.

2. A Palestinian action is an action initiated by the Palestinian side and an Israeli action is an action initiated by the Israelis. Confrontations are actions in which the initiators are not clear (the Palestinians or the Israelis), but both parties are involved.

3. We label groups as terrorist organizations on the basis of the EU-list of terrorist groups (EU, nd). This list includes Hamas, Islamic Jihad, Al Aqsa Martyrs' Brigades, and the Popular Front for the Liberation of Palestine.

\section{References}

Ackerman S (2001) Al-Aqsa intifada and the US Media. Journal of Palestine Studies 30(2): 61-74. Cohen B (1963) The Press and Foreign Policy. Princeton, NJ: Princeton University Press.

Cohen A, Adoni H Nossek H (1993) Television news and the intifada: a comparative study of social conflict. In Cohen A, and Wolfsfeld G (eds) Framing the Intifada. People and Media. New York: Ablex, 116-141.

De Bruijn J (2002) Nieuwsrubrieken hellen over naar Israëlische lezing. De Journalist 107(17): $28-31$.

Dente Ross S (2003) Unequal combatants on an uneven media battlefield: Palestine and Israel. In: Lester PM, Dente Ross S (eds) Images that Injure: Pictorial Stereotypes in the Media. Westport, CT: Praeger, 58-63.

Dunsky M (2001) Missing: the bias implicit in the absent. Arab Studies Quarterly 23(3): 1-21.

Entman RM (1991) Framing US coverage of international news: contrasts in narratives of the KAL and Iran air incidents. Journal of Communication 41(4): 6-26.

EU (nd) EU Position on Violence and Terrorism. Available at: http://europa.eu.int/comm/external relations/mepp/faq/index.htm

First A (1998) Who is the enemy? The portrayal of Arabs in Israeli television news. Gazette: The International Journal for Communication Studies 60(3): 239-251.

First A (2004) Are they still the enemy? The representation of Arabs in Israeli television news. In: Parfitt T (ed.) Jews, Muslims, and Mass Media. London: Routledge, 190-213.

Fisk R (2005) De grote beschavingsoorlog. Antwerp: Standaard Uitgeverij.

Gamson WA (1992) Talking Politics. Cambridge: Cambridge University Press.

Gamson W and Lasch KE (1983) The political culture of social welfare policy. In: Spiro SE, Yuchtman-Yaar E (eds) Evaluating the Welfare State. Social and Political Perspectives. New York: Academic Press, 397-415. 
Iyengar S and Kinder DR (1987) News that Matters. Chicago: University of Chicago Press.

Ismail A (2010) Making sense of a barrier: U.S. news discourses on Israel's dividing wall. Journal of Communication Inquiry 34(1): 85-108.

Korn A (2004) Reporting Palestinian casualties in the Israeli press: the case of Haaretz and the intifada. Journalism Studies 5(2): 247-262.

Krosnick JA and Brannon LA (1993) The impact of the Gulf War on the ingredients of presidential evaluations: multidimensional effects of political involvement. American Political Science Review 84(4): 963-975.

Krosnick JA and Kinder DR (1990) Altering the foundations of support for the President through priming. American Political Science Review 84(2): 497-512.

Liebes T and Kampf Z (2009) Black and white and shades of gray: Palestinians in the Israeli media during the 2nd intifada. International Journal of Press/Politics 14(4): 434-453.

Loughborough University Communications Research Centre (2006) The BBC's Reporting of the Israeli-Palestinian Conflict(August 12005 -January 31 2006), Research Report. Loughborough: Loughborough University.

Lowstedt A and Madhoun H (2003) The Intifada, Hasbara and the media. Palestine-Israel Journal 10(2): 47-56.

Mandelzis L (2003) The changing image of the enemy in the news discourse of Israeli newspapers, 1993-1994. Conflict and Communication Online 2(1): 1-12.

McCombs M (2004) Setting the Agenda: The Mass Media and Public Opinion. Cambridge: Polity Press.

McCombs M and Reynolds A (2002) News influence on our pictures of the world. In: Bryant J, Zillmann D (eds) Media Effects. Advances in Theory and Research. London: Lawrence Erlbaum, $1-18$.

McCombs M and Shaw D (1972) The agenda-setting function of mass media. Public Opinion Quarterly 36(2): 176-187.

McCombs M and Shaw D (1977) The agenda-setting function of the press. In: McCombs M and Shaw D (eds) The Emergence of American Political Issues: The Agenda-Setting Function of the Press. St. Paul Minnesota: West Publishing Co., 1-18.

McCombs M and Shaw D (1993) The evolution of agenda-setting research: twenty-five years in the marketplace of ideas. Journal of Communication 43(2): 58-67.

McQuail D (2005) McQuail's Mass Communication Theory. London: Sage.

Nir R and Roeh I (1992) Intifada coverage in the Israeli press: popular and quality papers assume a rhetoric of conformity. Discourse \& Society 3(1): 47-60.

Noakes J.A and Wilkins KG (2002) Shifting frames of the Palestinian movement in US news. Media, Culture \& Society 24(5): 649-671.

Pan Z, Kosicki G (1997) Priming and media impact on the evaluations of the President's performance. Communication Research 24(1): 3-30.

Philo G and Berry M (2004) Bad News from Israel. London: Pluto Press.

Philo G, et al. (2003) 'The Israeli-Palestinian conflict: TV news and public understanding. In: Thussu DK and Freedman D (eds) War and the Media. London: Sage, 133-148.

Picard RG and Adams PD (1991) Characterizations of acts and perpetrators of political violence in three elite U.S. daily newspapers. In: Alexander Y, Picard RG (eds) In the Camera's Eye: News Coverage of Terrorist Events. London: Brassey's, 12-22.

Rinnawi K (2007) De-legitimization of media mechanisms: Israeli press coverage of the Al Aqsa intifada. Gazette: The International Journal for Communication Studies 69(2): 149-178.

Rotik M (2006) BBC Governors' Impartiality Review on Coverage of the Israeli-Palestinian Conflict. Qualitative and Quantitative Audience Research Conducted by Opinion Leader Research in October and November 2005, Research Report. London: Opinion Leader Research. 
Semetko HA and Valkenburg PM (2000) Framing European politics: a content analysis of press and television news. Journal of Communication 50(2): 93-109.

Simmons BK (1991) U.S. newsmagazines' labeling of terrorists. In: Alexander Y, Picard RG (eds) In the Camera's Eye: News Coverage of Terrorist Events. London: Brassey's, 12-22.

Viser M (2003) Attempted objectivity: an analysis of the New York Times and Ha'aretz and their portrayals of the Palestinian-Israeli conflict. Press/Politics 8(4): 114-120.

Weimann G (1985) Terrorists or freedom fighters? Labeling terrorism in the Israeli press. Political Communication and Persuasion 2(4): 433-445.

Weimann G and Winn C (1993) The Theatre of Terror: Mass Media and International Terrorism. New York: Longman.

Zelizer B and Park D and Gudelunas D (2002) How bias shapes the news: challenging the New York Times' status as a newspaper of record on the Middle East. Journalism 3(3): 283-307.

\section{Biographical notes}

Annelore Deprez is as a senior researcher connected to the Department of Communication Studies at Ghent University. She is a member of the Centre for Journalism Studies (www. cjs.ugent .be). Her research interests include journalism studies, news analysis, political and international communication.

Karin Raeymaeckers is Professor at the Department of Communication Sciences, Ghent University and Director of the Center for Journalism Studies (www.cjs.ugent.be). She teaches politics and mass media, media structures and journalism and has published on a broad range of topics such as citizen journalism, EU communication and newspapers in education. Address: as Annelore Deprez. Email: Karin.Raeymaeckers@UGent.be 